\title{
POLYPS OF THE FAMILIES ATORELLIDAE AND NAUSITHOIDAE (SCYPHOZOA: CORONATAE) NEW TO THE BRAZILIAN FAUNA.
}

\author{
Gerhard Jarms \\ André Carrara Morandini \\ Fábio Lang da Silveira
}

Biota Neotropica v2 (n1) - http://www.biotaneotropica.org.br/v2n1/pt/abstract?article+BN01202012002

\author{
Received: march/26/2002 \\ Revised: april/25/2002 \\ Accepted: april/29/2002 \\ Gerhard Jarms Zoologisches Institut und Zoologisches Museum, Universität Hamburg, \\ Martin-Luther-King Platz 3, 20146 Hamburg, Germany, \\ e-mail: Gerhard.Jarms@ zoologie.uni-hamburg.de \\ Tel.: +49-40-428382086 Fax: +49-40-428382086 \\ André Carrara Morandini and Fábio Lang da Silveira \\ (correspondence author; correspondência para) Departamento de Zoologia, Instituto de Biociências, \\ Universidade de São Paulo, C.P. 11461, 05422-970, São Paulo, SP, Brazil, \\ e-mail: acmorand@usp.br, fldsilve@usp.br \\ Tel.:+55-11-30917619 Fax: +55-11-30917513
}

\begin{abstract}
Solitary scyphistomae of the scyphozoan order Coronatae were sorted from samples collected at 12 oceanographic stations of the Revizee-Score Sul/Bentos project along the Brazilian coast. The 201 specimens were found, at depths between 133$808 \mathrm{~m}$, growing on stony corals. These scyphistomae were assigned to the families Nausithoidae (186) and Atorellidae (15) based on the outer morphology of the periderm tubes. The number and shape of the cusps, and the presence of second order teeth in some of them, suggests that the polyps should be split into four types, two of them assigned to Nausithoe Kölliker, 1853 and two others to Atorella Vanhöffen, 1902. Living stephanoscyphistomae should be collected and reared to further resolve the taxonomy of these scyphozoans.
\end{abstract}

Keywords Coronatae Nausithoe Atorella Brazil

\section{Resumo}

Cifístomas solitários de cifozoários da ordem Coronatae foram triados a partir de amostras coletadas em 12 estações oceanográficas do projeto Revizee-Score Sul/Bentos na costa brasileira. Foram encontrados 201 espécimes, entre as profundidades de 133-808 m, crescendo sobre corais pétreos. Estes cifístomas foram identificados nas famílias Nausithoidae (186) e Atorellidae (15) com base na morfologia externa dos tubos peridérmicos. O número e forma dos espinhos internos, e presença de dentes de segunda ordem em alguns espinhos, sugere que os pólipos sejam separados em quatro tipos, dois deles identificados como Nausithoe Kölliker, 1853 e outros dois como Atorella Vanhöffen, 1902. Estefanocifístomas vivos deveriam ser coletados e cultivados para melhor esclarecer a taxonomia destes cifozoários.

Palavras-chave Coronatae Nausithoe Atorella Brasil 


\section{Introduction}

Coronatae have been hypothesized to be a basal group of the Scyphozoa (Werner, 1973). Fossil Conulariida and Byroniida, either close relatives or perhaps the ancestors of recent coronates, are known from the Cambrian (Scrutton, 1979). Life-cycle studies of this metagenetic cnidarian group have led to recognition of characters that may support phylogenetic analyses within the group, and suggest the events leading to speciation in the group.

Only three species of coronate polyps are described for the Brazilian fauna: Stephanoscyphistoma corniformis (Komai, 1936) by Silveira and Morandini (1996), Linuche unguiculata (Swartz, 1788) by Silveira and Morandini (1998), and Nausithoe aurea Silveira and Morandini, 1997. In this paper the periderm tubes of coronate polyps (= stephanoscyphistomae) collected off the Brazilian coast are described and at least four types (probably separate species) are new to the Brazilian fauna.

The relationships of these western South Atlantic forms to known species are discussed especially in comparison with those distributed on the eastern coasts of the North Atlantic and the Mediterranean.

\section{Material and methods}

Samples of benthic fauna were collected during two cruises of the oceanographic ship Prof. W. Besnard for the REVIZEE ("Score Sul, Bentos") project. The cruises were based on lines perpendicular to the coast (radials), with approximately 20 nautical miles in between. On each cruise 4-10 radials and 15-32 oceanographic stations were marked. The polyps were sorted among a large number of different substrates by MSc Alberto Lindner, a trained zoologist in Cnidaria groups. All samples of coronate polyps were attached to the calcareous skeletons of stony corals (Scleractinia), and were preserved in $70 \%$ alcohol. The available oceanographic data are provided in Tab. 1.

Selected voucher specimens of these various morphotypes have been deposited in the collection of the "Museu Nacional da Universidade Federal do Rio de Janeiro (MNRJ)". Nausithoe: MNRJ 4179 4182, ten polyps, from a depth of 147 to $417 \mathrm{~m}$; Atorella: MNRJ 4183 , two polyps, from a depth of 417 m.Measurements of all tubes were taken according to Jarms (1991). Length and diameter were measured, and the Formquotient (FQ), the ratio between diameter and length, calculated only for complete undisturbed tubes i.e. with no significant injury observed. The number of transverse rings per $0.4 \mathrm{~mm}$ was counted in straight parts of the tubes to quantify the outer structure.

Selected periderm tubes of the different types were washed in distilled water. Just above each ring of the internal cusps, the tubes were cut. The pieces were cleaned of tissue and glued on slides for electron microscopy. After being sputtered with gold they were examined using a scanning electron microscope at the Zoological Department of the University of Hamburg.
Results

The outer structures of the examined tubes, namely the rugae on the surface, are different indicating the presence of several groups (Figs 1, 2 and 3). Parts of straight growth (Fig. 1) in the first group (genus Atorella) have a narrow (about $8-16$ rings per $0.4 \mathrm{~mm}$ ) but prominent pattern of horizontal rings with small nearly regular vertical chambers. In the second group (genus Nausithoe), the outer structure is characterized by the greater distance of the horizontal rings (about $2-3$ per $0.4 \mathrm{~mm}$ ), and the rounded, more irregular, vertical structures. However there are two types in this group: one with prominent rings with sharp edges (Fig. 2) and the other with smooth rings (Fig. $3)$.

Transverse sections of the tubes, just above the whorls of the internal cusps, show further differences, thus possibly indicating separate types within groups. The number of cusps per whorl, at least in the upper ones, in the examined tubes of genus Nausithoe is 8 (Fig. 4) or 16 (Fig. 5 ). The cusps themselves differ in shape. Their margin can be more or less smooth or with lateral teeth. There is a gradient from thorny to smooth from the base to the top of the tube (Plate 1 and 2). Teeth of a second order on the upper or under side of cusps are either present or absent in the basal whorls of the genus Atorella (Plate 3).

Table 2 is a combination of new data and available data from previous works for systematic studies on coronate polyps.

\section{Discussion}

Within the order Coronatae, polyps are described from the families Linuchidae, Nausithoidae and Atorellidae (Jarms, 1997). Periphyllidae have direct development without polyps (Jarms et al., 1999). Ripe eggs in the Periphyllidae, Paraphyllinidae, and Atollidae are roughly ten times larger than in other scyphozoan medusae (Morandini and Silveira, 2001, and unpublished data), due to the amount of yolk. We presume that the deep sea families Atollidae and Paraphyllinidae also lack a polyp generation as in the Periphyllidae. The polyps of the Linuchidae are colonial (Werner, 1979; Silveira and Morandini, 1998). Thus, the collected stephanoscyphistomae belong to the families Nausithoidae or Atorellidae.

The outer structure of the periderm tube is characteristic of and useful for identification of the families. In Atorella the horizontal rings are narrower, and the vertical structures are clearly to be seen (Fig. 1). This is confirmed by rearing experiments characterizing the life cycles of nine solitary Nausithoe species and three Atorella species (Jarms, 1997, 2001).

Useful characters to distinguish species are found in the cusps, although there are intraspecific variations and changes in shape from base to top of the same tube (Plate 1) (compare Jarms, 1990 plates I, II, IV, V, VI). Up to now all Atorella have 8 cusps per whorl (Tab. 2). As second order cusps in the Nausithoidae are exclusive, and therefore specific for $N$. werneri (Table 2), we conclude that they 
may also be specific in the family Atorellidae. Therefore we believe the two Atorella types to be different species, and their measurements are very close to the undescribed species from the NE Atlantic (Tab. 2). Without knowing the life cycle, we cannot determine which species they may be or whether they are undescribed. We know of five species of the genus Atorella. The life cycle of A. vanhoeffeni Bigelow, 1909 is known (Werner, 1966) as well as that of $A$. japonica Kawaguti and Matsuno, 1981. Three species are described only from their medusae: A. arcturi Bigelow, 1928 from the tropical Pacific, A. subglobosa Vanhöffen, 1902 from the east coast of Africa, and also collected west of the Canary Islands, the Atlantic Ocean (Ranson, 1945), and A. octogonos Mills et al., 1987 from the Bahamas, the Atlantic Ocean. The undescribed Atorella polyps in the first author's laboratory were also collected from the Atlantic Ocean, off the coast of Morocco. They had already strobilated but we have not yet succeeded in raising them to mature medusae. Accordingly, we are uncertain whether they are the polyps of previously described medusae. The same problem exists with the polyps of the REVIZEEcollection.

The ranges of the Formquotients of Nausithoe species vary between the slender $N$. thieli and Thecoscyphus zibrowii, the thickest species (Table 2). The two Nausithoe groups in this work ( 8 and 16 cusps) are close together in the FQ 2mm, similar to $N$. marginata, and in the FQ $5 \mathrm{~mm}$ close to the values for $N$. marginata and $N$. aurea. Species identification only by these figures is impossible. The number of cusps in Nausithoe can vary from base to top but with constant differences in the species (Jarms, 1991). In our material we inspected the upper whorls as far as they can be seen without dissection. Only some specimens of each group were cut (Plate 1). Eight (Fig. 4) or 16 (Fig. 5) teeth in the terminal whorls are stable characters. Thus, we can define at least two different species in the Nausithoe material. The tubes with 16 cusps are assigned to a known species, and those with 8 cusps to an undescribed species. The similarity of the collected 16cusp polyps to $N$. aurea is also suggested by the FQ $5 \mathrm{~mm}$ (Table 2). Nevertheless, behind the 16- as well as the 8cusp tubes more than one species may be concealed.

The species Nausithoe aurea is closely related to the species $N$. maculata from the eastern Atlantic Ocean, and to $N$. planulophora from the Mediterranean, for besides the 16 cusps, they also possess another shared character of the soft body usually visible in living specimens: white spots between the tentacle bases. The grouping of these species is confirmed by cladistic analysis using 44 characters (Jarms, in prep.). Possibly the other collected Brazilian types may have closely related species in the North-East Atlantic Ocean, which could lead to a novel distribution. Only the cultivation of living specimens can help to answer these questions.

The sorted-out specimens with prominent rings, marked with a "*" in Table 1 and measured separately in Table 2, are not clearly separate from the other Nausithoe specimens with 16 cusps per upper whorl, by their
Formquotient. In our cultured material of Nausithoe aurea we found tubes with normal outer structures and with prominent rings as well.

Among the collected stephanoscyphistomae there were some remarkable dark specimens that could be regarded as different types. The problem of dark tubes has already been discussed by Kramp (1959). Although Kramp could not classify the polyps in terms of species, he found a correlation of total length and number of whorls of cusps inside the tubes with the dark colour. The same darkness and length phenomenon is to be seen in the polyps of the species Nausithoe eumedusoides (Werner, 1974).

As only preserved stephanoscyphistomae were studied we are not able to determine species. But there are certain similarities with identified coronate polyps from the East Atlantic. So, it is necessary to collect live material to elucidate the respective life cycles. The results could provide further characters for phylogeny of the group and useful information about distribution, such as we have for the species group $N$. maculata, N. aurea, and $N$. Planulophora.

\section{Acknowledgements}

This work was supported by Fundação de Amparo à Pesquisa do Estado de São Paulo (FAPESP 99/12433-0) and CAPES/USP PROAP/2000. We are indebted to MSc A. Lindner for sorting the scyphistomae periderm tubes, to Dr A.C.Z. do Amaral (UNICAMP) for donating the Revizee material and to Renate Walter (University of Hamburg) for help with the electron microscopy. We thank an anonymous reviewer for improving the English. We thank CEBIMar USP for providing part of the required facilities to examine the material at the start of this work.

\section{References}

BIGELOW, H.B. 1909. Reports on the scientific results of the expedition to the eastern tropical Pacific, in charge of Alexander Agassiz, by the U.S. Fish Commission steamer 'Albatross', from October, 1904 to March, 1905, Lieut. Commander L.M. Garret, U.S.N., commanding. XVI. The medusae. Mem. Mus. Comp. Zool. Harv. 37: 1-243.

BIGELOW, H.B. 1928. Scyphomedusae from the Arcturus Oceanographic Expedition. Zoologica, N.Y. 8(10): 495-524.

JARMS, G. 1988. Zur Morphologie, Biologie und Systematik der Nausithoidae (Coronata, Scyphozoa), mit Bestimmungsschlüsseln für Polypen und Medusen, der Beschreibung dreier neuer Arten und einer bisher unbekannten Planuloidbildung. Thesis Fachbereich Biologie. Universität Hamburg, Hamburg.

JARMS, G. 1990. Neubeschreibung dreier Arten der Gattung Nausithoe (Coronata, Scyphozoa) sowie Wiederbeschreibung der Art Nausithoe marginata Kölliker, 1853. Mitt. hamb. zool. Mus. Inst. 87: 7-39. 
JARMS, G. 1991. Taxonomic characters from the polyp tubes of coronate medusae (Scyphozoa, Coronatae). Hydrobiologia 216/217: 463-470.

JARMS, G. 1997. The polyps of Coronatae (Scyphozoa), a review and some new results. In Proceedings of the 6th International Conference on Coelenterate Biology (J.C. den Hartog, ed.). Nationaal Natuurhistorisch Museum, Leiden, p. 271-278.

JARMS, G. 2001. The life cycle of Nausithoe hagenbecki sp. nov. (Scyphozoa, Coronatae). Mitt. hamb. zool. Mus. Inst. 98: 13-22.

JARMS, G., BåMSTEDT, U., TIEMANN, H., MARTINUSSEN, M.B. \& FOSSå, J.H. 1999. The holopelagic life cycle of the deep-sea medusa Periphylla periphylla (Scyphozoa, Coronatae). Sarsia 84: 55-65.

KAWAGUTI, S. \& MATSUNO, A. 1981. A new species of the Coronatae, Scyphozoa, from the Japan sea; Atorella japonica n. sp. Bull. Kawasaki Parmed. Coll. 1: 15-21.

KOMAI, T. 1936 On another form of Stephanoscyphus found in the waters of Japan. Mem. Coll. Sci. Kyoto (Ser. B) 11(3):175-83.

KRAMP, P. L. 1959. Stephanoscyphus (Scyphozoa). Galatea Rep. 1: 173-185.

MORANDINI, A.C. \& SILVEIRA, F.L. da. 2001. Sexual reproduction of Nausithoe aurea (Scyphozoa, Coronatae). Gametogenesis, egg release, embryonic development, and gastrulation. Sci. Mar. 65(2): 139-149.

MILLS, C.E., LARSON, R.J. \& YOUNGBLUTH, M.J. 1987. A new species of coronate scyphomedusa from the Bahamas, Atorella octogonos. Bull. Mar. Sci. 40(3): 423-427.

RANSON, G. 1945. Scyphoméduses provenant des Campagne du Prince Albert 1er de Monaco. Richard, M.J., Monaco.

SCRUTTON, C.T. 1979. Early fossil Cnidarians. In The origin of major invertebrate groups (M.R. House, ed.). Academic Press, London, p. 161-207.

SILVEIRA, F.L. da. \& MORANDINI, A.C. 1996. Stephanoscyphistoma corniformis (Komai, 1936)(Cnidaria, Scyphozoa, Coronatae) from the north coast of Sao Paulo, Brazil. Semina 17(2): 137-145.

SILVEIRA, F.L. da. \& MORANDINI, A.C. 1997. Nausithoe aurea n. sp. (Scyphozoa: Coronatae: Nausithoidae), a species with two pathways of reproduction after strobilation: sexual and asexual. Cont. Zool. 66(4): 235-246.

SILVEIRA, F.L. da. \& MORANDINI, A.C. 1998. Asexual reproduction in Linuche unguiculata (Swartz, 1788) (Scyphozoa: Coronatae) by planuloid formation through strobilation and segmentation. Proc. biol. Soc. Wash. 111(4): 781-794.
SöTJE, I. 1998. Untersuchungen zur Ontogenese von Thecoscyphus zibrowii Werner, 1984 (Cnidaria, Scyphozoa). Diplomarbeit Fachbereich Biologie. Universität Hamburg, Hamburg.

SWARTZ, O. 1788. Medusa unguiculata och Actinia pusilla. K. svenska Vetensk Akad. Handl. 9:198202.

WERNER, B. 1966. Stephanoscyphus (Scyphozoa, Coronatae) und seine direkte Abstammung von den fossilen Conulata. Helgoländer wiss. Meeresunters. 13: 317-347.

WERNER, B., 1973. New investigations on systematics and evolution of the class Scyphozoa and the Phylum Cnidaria. Publs Seto mar. biol. Lab. 20: 35-61.

WERNER, B. 1974. Stephanoscyphus eumedusoides n. sp. (Syphozoa, Coronatae), ein Höhlenpolyp mit einem neuen Entwicklungsmodus. Helgoländer wiss. Meeresunters. 26: 434-463.

WERNER, B. 1979. Coloniality in the Scyphozoa: Cnidaria. In Biology and systematics of colonial organisms (G. Larwood, \& B.R. Rosen, eds.). Academic Press, London, p. 81-103.

VANHöFFEN, E. 1902. Die Acraspeden Medusen der deutschen Tiefsee-Expedition 1898-1899. Wiss. Ergebn. 'Valdivia' 3: 1-52.

Títle: Polyps of the families atorellidae and nausithoidae (scyphozoa: coronatae) new to the brazilian fauna.

Authors: Gerhard Jarms, André Carrara Morandini and Fábio Lang da Silveira

Biota Neotropica, Volume 2, número 1, 2002 -

http://www.biotaneotropica.org.br/v2n1/pt/abstract?articl e+BN01202012002

Received: march/26/2002

Revised: april/25/2002

Accepted: april/29/2002

ISSN 1676-0603 


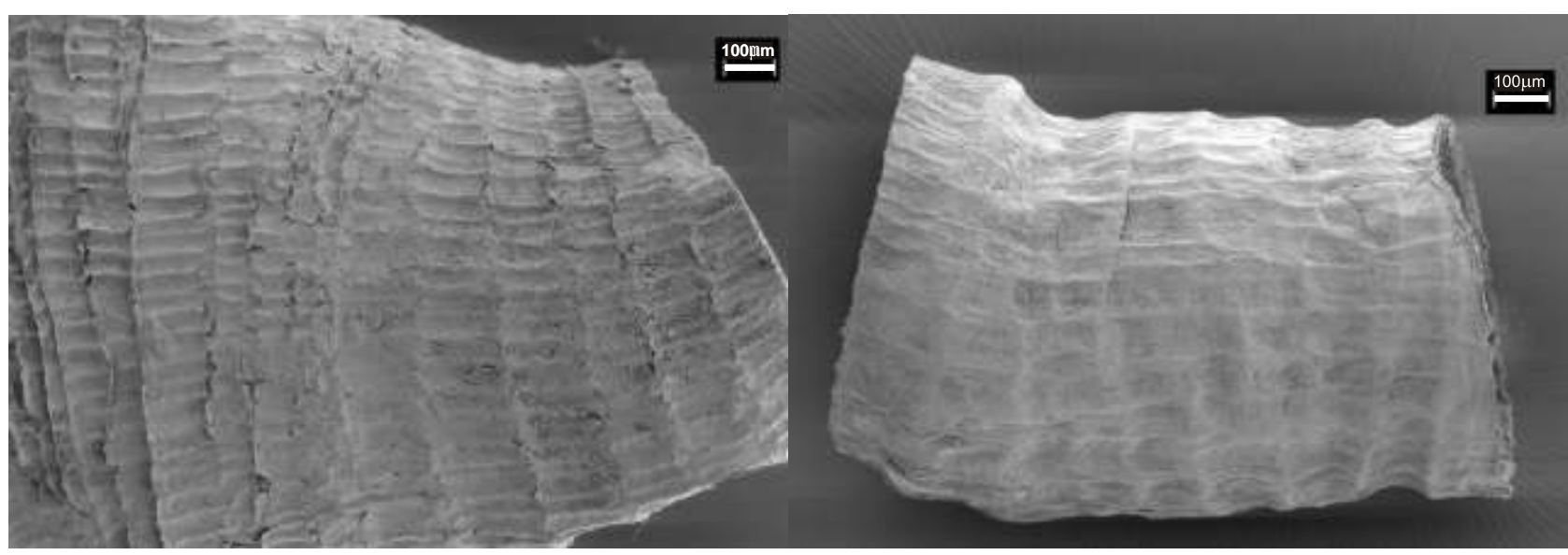

Fig. 1. Atorella left side and Nausithoe. right side: outer structure of the tube

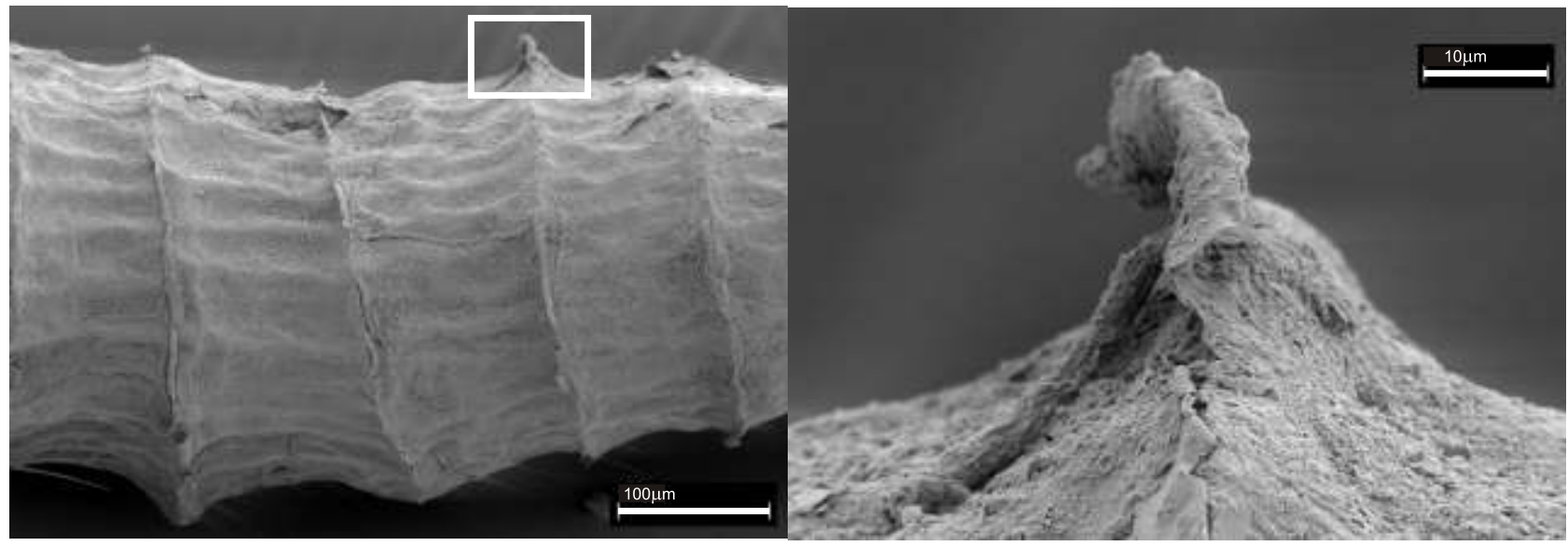

Fig. 2. Nausithoe type 1: a, outer structure of the tube with 5 rings; b, enlarged area (white box) from a.

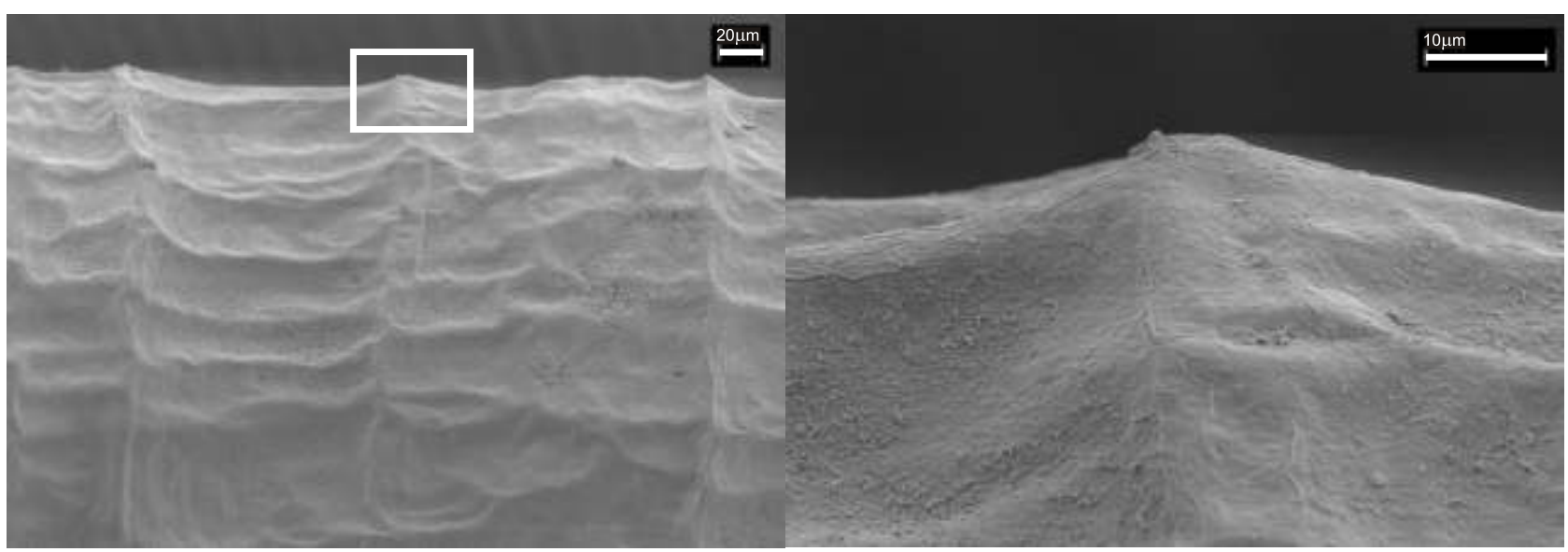

Fig. 3. Nausithoe type 2: a, outer structure of the tube with 4 rings; b, enlarged area (white box) from a. 


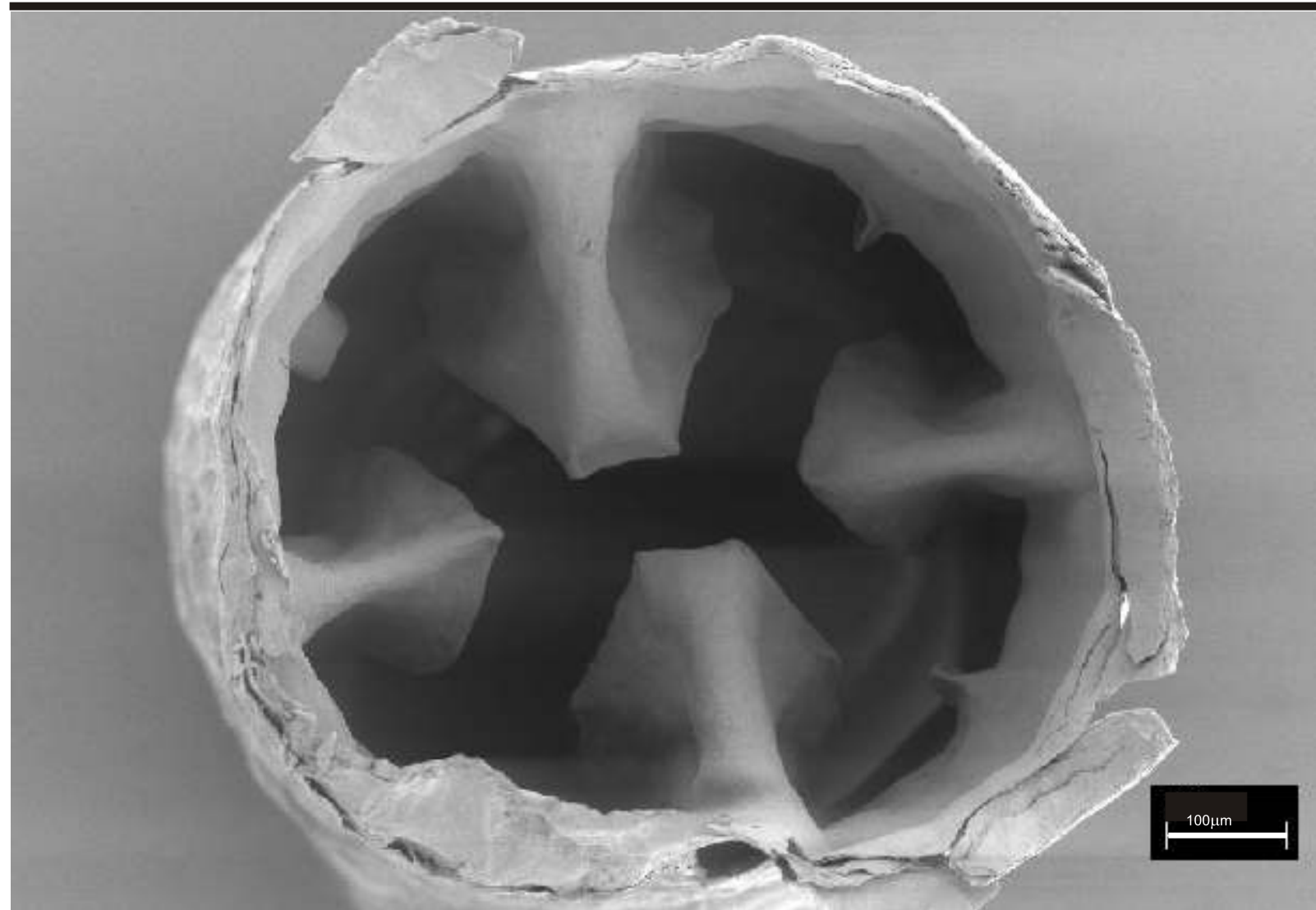

Fig. 4. Nausithoe type 3 whorl with 8 teeth.

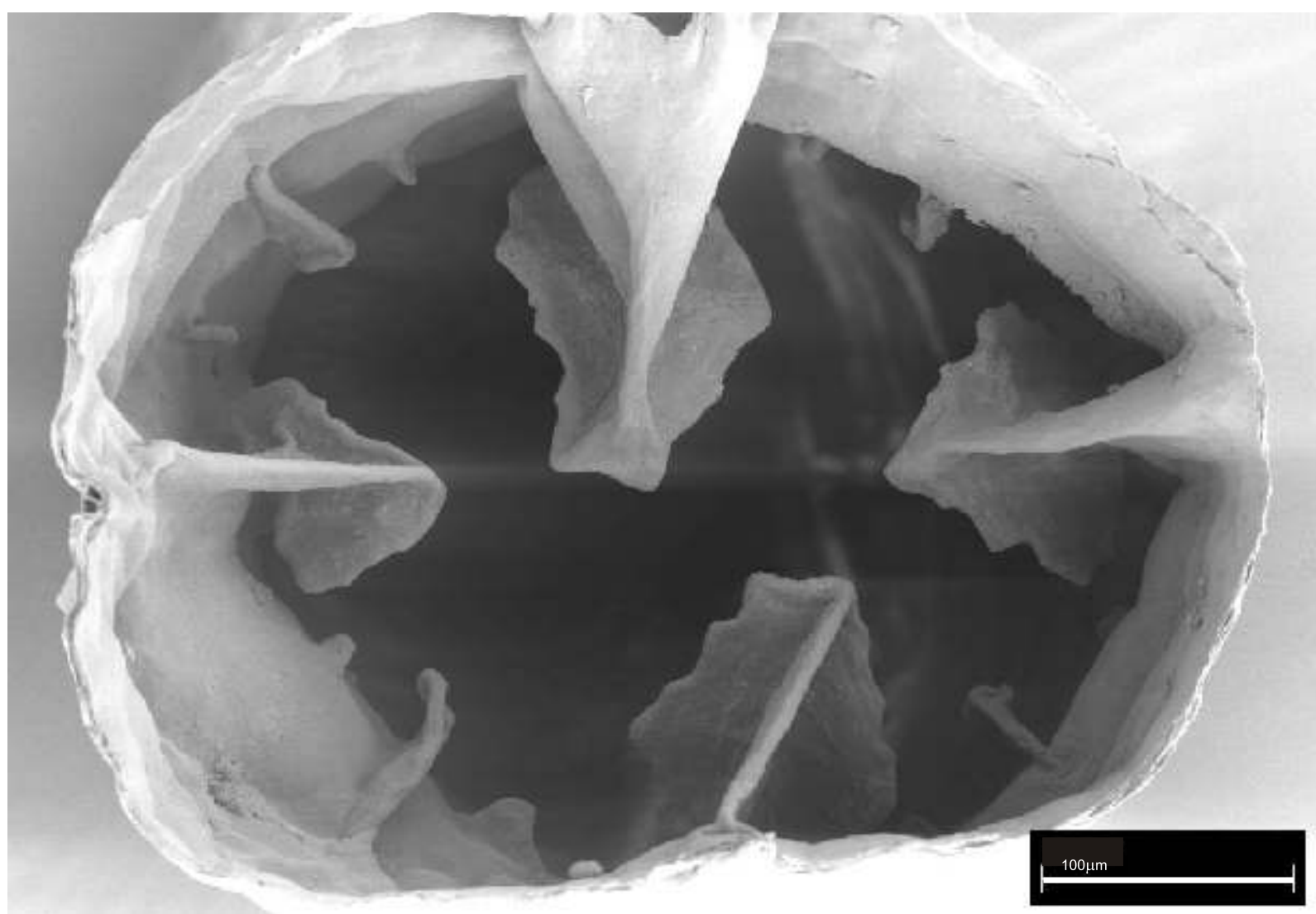

Fig. 5. Nausithoe type 1 or 2 , whorl with 16 teeth. 

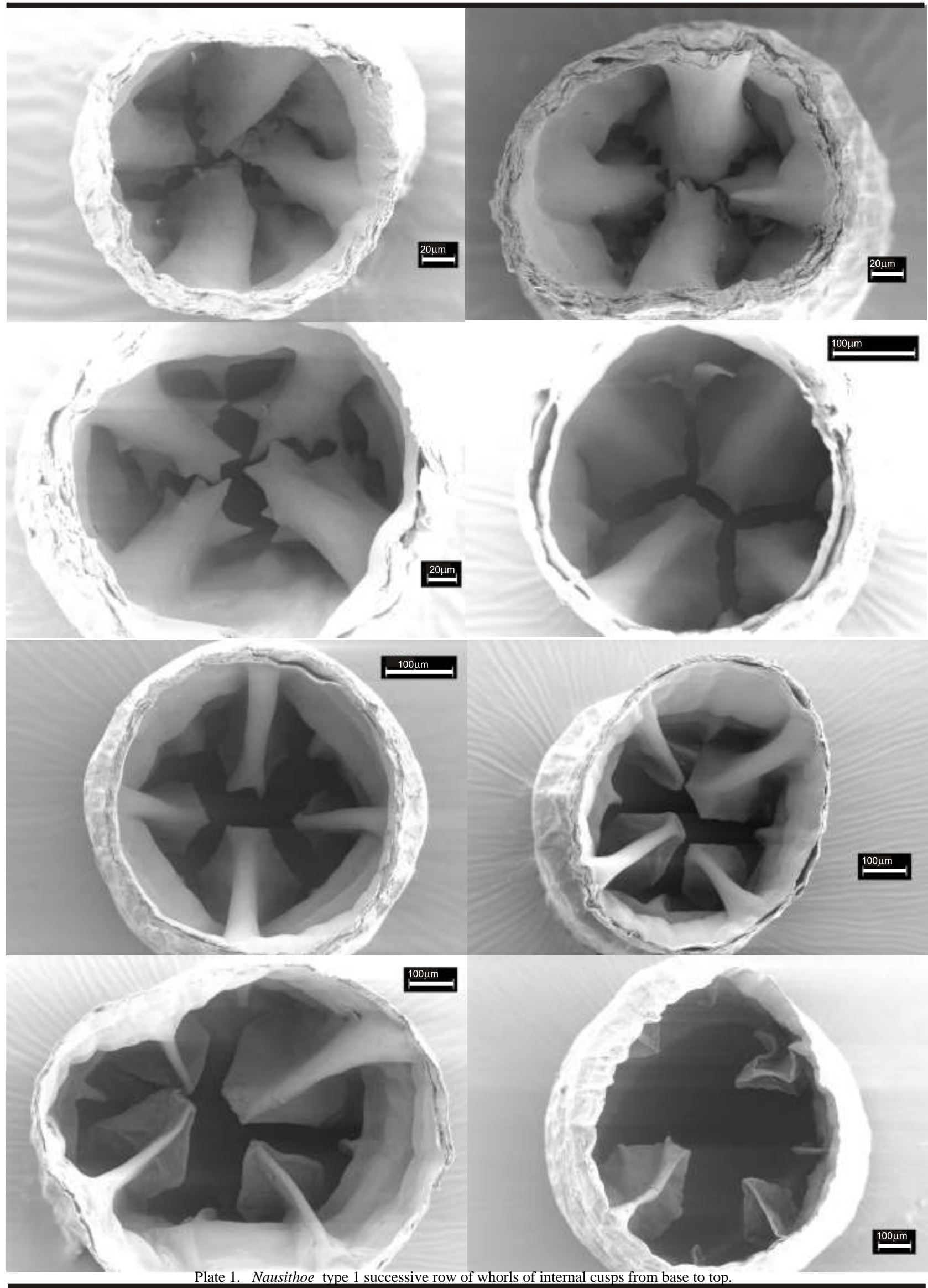

http://www.biotaneotropica.org.br 

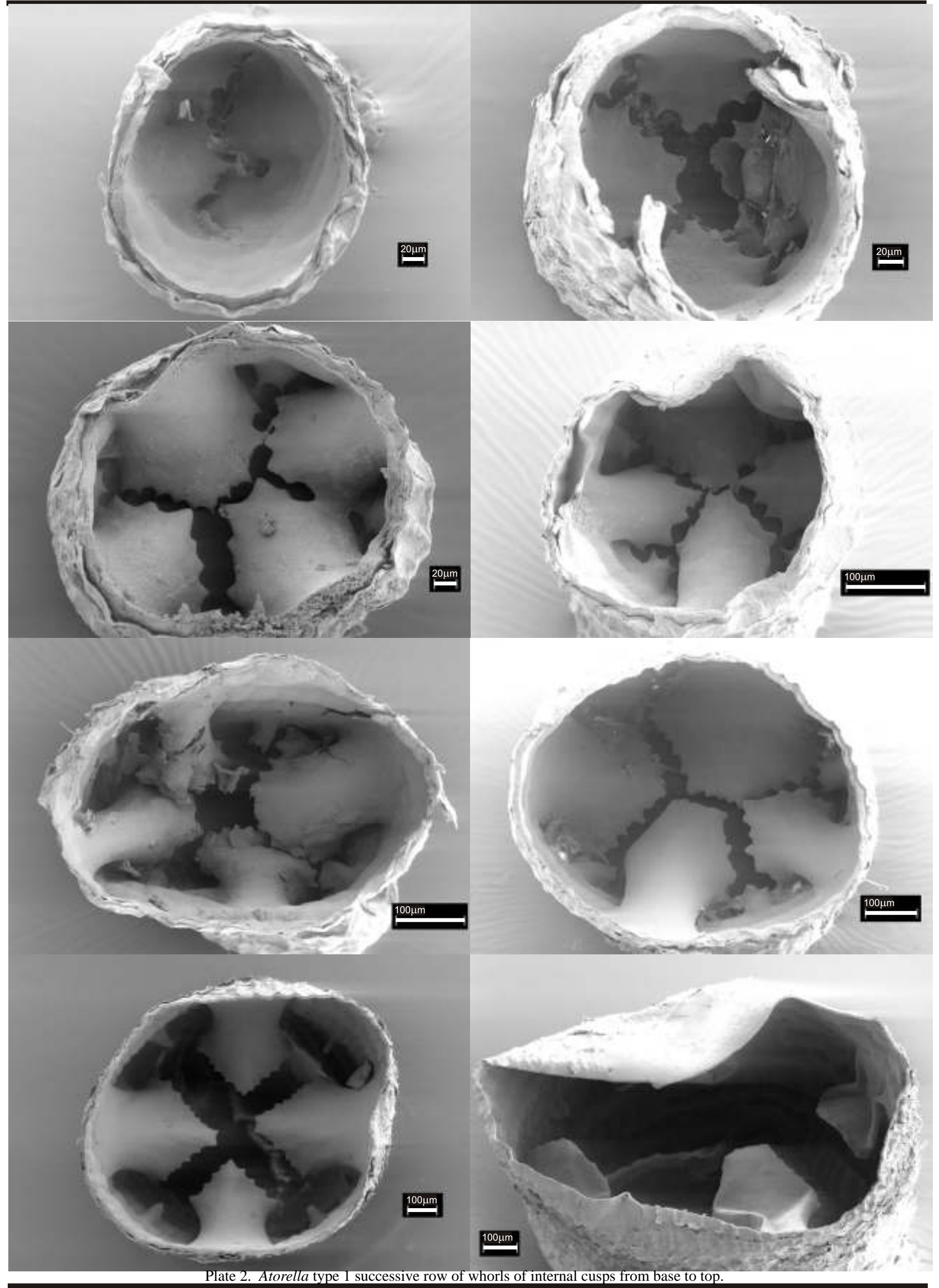

http://www.biotaneotropica.org.br 


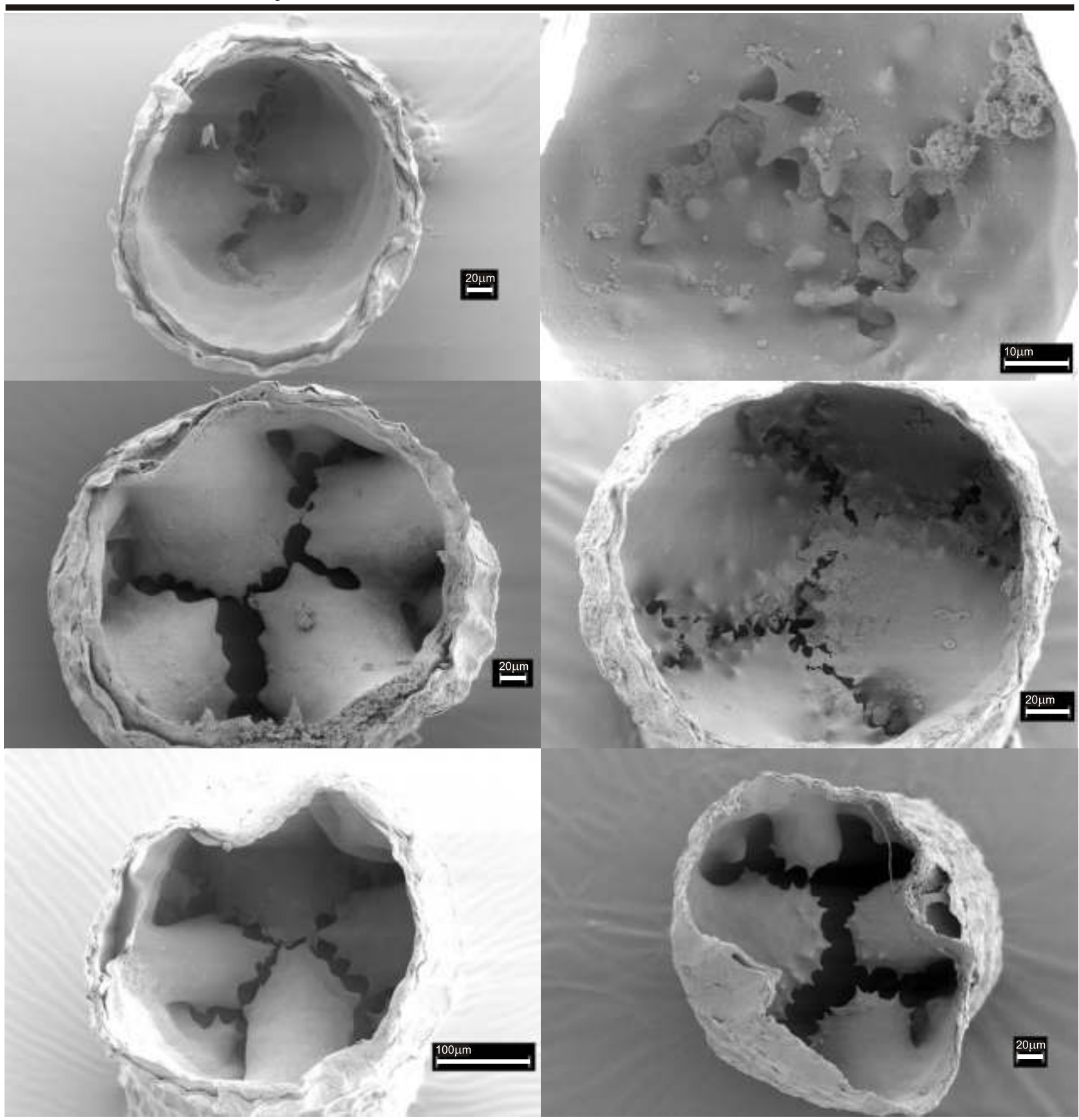

Plate 3. Comparison of 1, 3, 4 whorls of internal cusps of a specimen of Atorella type 1 (left column) and Atorella type 2 (right column) respectively. 


\begin{tabular}{|c|c|c|c|c|c|c|c|c|c|c|}
\hline Station & radial & Sampler & Date & $\begin{array}{c}\text { Depth } \\
(\mathbf{m})\end{array}$ & $\mathrm{n}^{0}$ of specimens & Lat. Long. & Pressure & $\begin{array}{c}\text { Temp } \\
\left({ }^{\circ} \mathrm{C}\right)\end{array}$ & $\begin{array}{c}\text { Salinity } \\
(\% \circ)\end{array}$ & Density \\
\hline 6650 & Pilot & Van Veen (1) & 15.Dec.97 & 417 & $\begin{array}{c}10 \text { Atorella } 57 \text { Nausithoe } \\
23 \text { Nausithoe* }\end{array}$ & $25^{\circ} 57.39^{\prime} \mathrm{S} 45^{\circ} 34.25^{\prime} \mathrm{W}$ & & & & \\
\hline 6661 & 1 & dredge $(7,2)$ & 09.Jan.98 & 147 & 37 Nausithoe & $24^{\circ} 07.637^{\prime} \mathrm{S} 45^{\circ} 51.895^{\prime} \mathrm{W}$ & & & & \\
\hline 6665 & 2 & BTG (2) & 10.Jan.98 & 258 & 3 Atorella, 30 Nausithoe & $24^{\circ} 20.844^{\prime} \mathrm{S} 44^{\circ} 09.913^{\prime} \mathrm{W}$ & 260.86 & 13.0971 & 35.2129 & 26.5389 \\
\hline 6666 & 2 & beam trawl & 10.Jan.98 & 163 & 19 Nausithoe & $24^{\circ} 17.129^{\prime} \mathrm{S} 44^{\circ} 12.179^{\prime} \mathrm{W}$ & 157.89 & 14.2420 & 35.3969 & 26.4433 \\
\hline 6671 & 3 & Van Veen (3) & 11.Jan.98 & 260 & 4 Nausithoe & $24^{\circ} 32.091^{\prime} \mathrm{S} 44^{\circ} 27.045^{\prime} \mathrm{W}$ & 258.90 & 13.56 & 35.32 & 26.52 \\
\hline 6673 & 3 & dredge (2) & 11.Jan.98 & 133 & 1 Nausithoe & $24^{\circ} 17.939^{\prime} \mathrm{S} \quad 44^{\circ} 35.983^{\prime} \mathrm{W}$ & 135.33 & 13.52 & 35.29 & 26.51 \\
\hline 6676 & 4 & dredge (2) & 13.Jan.98 & 153 & 2 pieces & $24^{\circ} 49.699^{\prime} \mathrm{S} 44^{\circ} 44.965^{\prime} \mathrm{W}$ & 147.10 & 16.58 & 35.75 & 26.19 \\
\hline 6679 & 5 & Dredge (2), BTG (2) & 12.Jan.98 & 808 & 2 Atorella, 1 Nausithoe & $25^{\circ} 18.874^{\prime} \mathrm{S} \quad 44^{\circ} 52.516^{\prime} \mathrm{W}$ & & & & \\
\hline 6680 & 5 & Box corer (2) & 12.Jan.98 & 258 & 2 Nausithoe & $25^{\circ} 15.064^{\prime} \mathrm{S} \quad 44^{\circ} 52.865^{\prime} \mathrm{W}$ & 229.48 & 14.719 & 35.446 & 26.378 \\
\hline 6685 & 6 & Van Veen (2) & 13.Jan.98 & 282 & 1 piece & $25^{\circ} 41.827^{\prime} \mathrm{S} \quad 45^{\circ} 11.686^{\prime} \mathrm{W}$ & 272.63 & 14.079 & 35.384 & 26.468 \\
\hline 6686 & 6 & dredge & 13.Jan.98 & 153 & 2 Nausithoe & $25^{\circ} 36.988^{\prime} \mathrm{S} \quad 45^{\circ} 13.571^{\prime} \mathrm{W}$ & 159.85 & 14.95 & 35.47 & 26.35 \\
\hline 6693 & 10 & BTG (2) dredge & 19.Jan.98 & 430 & 11 Nausithoe & $26^{\circ} 41.273^{\prime} \mathrm{S} 46^{\circ} 27.005^{\prime} \mathrm{W}$ & 374.614 & 11.491 & 34.9985 & 26.6846 \\
\hline
\end{tabular}

Table 1. Stephanoscyphistomae collected during part of the REVIZEE campaigns. Blank spaces in the table represent unavailable data. *Polyps with prominent ring structures. 


\begin{tabular}{|c|c|c|c|c|c|c|}
\hline Species/ type & \begin{tabular}{cc}
\multicolumn{2}{c}{ FQ 2mm } \\
n & $\mathbf{m v}$
\end{tabular} & 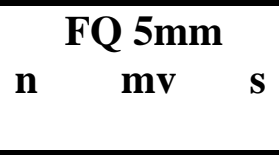 & $\begin{array}{c}\mathbf{n} \\
\text { whorls }\end{array}$ & $\begin{array}{l}\text { cusps } \\
\text { whorl }\end{array}$ & $\begin{array}{c}\text { cusps } \\
2.0 \text {.order }\end{array}$ & $\begin{array}{c}\text { rings } \\
\text { per } \\
0.4 \mathrm{~mm}\end{array}$ \\
\hline Nausithoe type 3 & $\begin{array}{c}15 \mathbf{0 . 1 4 6} \\
0.026\end{array}$ & $\begin{array}{c}12 \mathbf{0 . 0 9 7} \\
0.015\end{array}$ & $5-10$ & 8 & & $4-5$ \\
\hline $\begin{array}{c}\text { Nausithoe all } \\
\text { type } 1 \text { - prominent } \\
\text { rings } \\
\text { type } 2 \text { - normal rings }\end{array}$ & $\begin{array}{cc}41 & \mathbf{0 . 1 4 7} \\
0.022 \\
15 \quad \mathbf{0 . 1 5 3} \\
0.025 \\
26 \quad \mathbf{0 . 1 4 3} \\
0.020\end{array}$ & $\begin{array}{cc}32 & \mathbf{0 . 0 9 9} \\
0.024 \\
11 \quad \mathbf{0 . 1 1 0} \\
0.030 \\
21 \quad \mathbf{0 . 0 9 4} \\
0.017\end{array}$ & $\begin{array}{l}4-11 \\
4-11 \\
4-11\end{array}$ & 16 & & $\begin{array}{l}4-5 \\
4-5 \\
4-5\end{array}$ \\
\hline ***Nausithoe aurea & $\begin{array}{c}25 \mathbf{0 . 1 9 5} \\
0.032\end{array}$ & $\begin{array}{c}12 \mathbf{0 . 1 1 0} \\
0.025\end{array}$ & $3-7$ & 16 & & $4-5$ \\
\hline *Nausithoe maculata & $\begin{array}{c}10 \quad \mathbf{0 . 1 7 7} \\
0.033\end{array}$ & $\begin{array}{c}10 \mathbf{0 . 1 3 5} \\
0.002\end{array}$ & $6-8$ & 16 & & $4-5$ \\
\hline $\begin{array}{c}* \text { Nausithoe } \\
\text { planulophora }\end{array}$ & $\begin{array}{c}10 \mathbf{0 . 1 9 3} \\
0.025\end{array}$ & $\begin{array}{c}10 \mathbf{0 . 1 3 2} \\
0.018\end{array}$ & $5-7$ & 8,16 & & $3-5$ \\
\hline $\begin{array}{c}\text { *Nausithoe } \\
\text { marginata } \\
\text { (laboratory reared) }\end{array}$ & $\begin{array}{lc}5 & \mathbf{0 . 1 4 2} \\
& 0.015 \\
8 & \mathbf{0 . 1 5 4} \\
& 0.010 \\
\end{array}$ & $\begin{array}{lc}5 & \mathbf{0 . 0 9 6} \\
& 0.013 \\
8 & \mathbf{0 . 1 0 6} \\
0.003 \\
\end{array}$ & $\begin{array}{l}5-10 \\
5-10\end{array}$ & $\begin{array}{l}8 \\
8\end{array}$ & & $\begin{array}{l}3-4 \\
3-4\end{array}$ \\
\hline *Nausithoe werneri & $\begin{array}{c}14 \mathbf{0 . 1 6 3} \\
0.022\end{array}$ & $\begin{array}{c}14 \mathbf{0 . 1 1 7} \\
0.015\end{array}$ & $6-11$ & 8 & present & $2-3$ \\
\hline *Nausithoe thieli & $\begin{array}{cc}9 & \mathbf{0 . 0 8 8} \\
0.017\end{array}$ & $\begin{array}{c}9 \mathbf{0 . 0 6 5} \\
0.006\end{array}$ & $1-7$ & $2,4,8$ & & $5-8$ \\
\hline $\begin{array}{c}\text { **Thecoscyphus } \\
\text { zibrowii }\end{array}$ & $\begin{array}{c}44 \mathbf{0 . 3 7 0} \\
0.037\end{array}$ & $\begin{array}{c}44 \mathbf{0 . 2 4 4} \\
0.030\end{array}$ & & & & $2-3$ \\
\hline Atorella vanhoeffeni & $\begin{array}{c}10 \quad \mathbf{0 . 5 0 2} \\
0.127\end{array}$ & $\begin{array}{c}10 \quad \mathbf{0 . 2 5 3} \\
0.035\end{array}$ & $2-4$ & 8 & & $2-5$ \\
\hline $\begin{array}{c}\text { Atorella sp NE } \\
\text { Atlantic }\end{array}$ & $\begin{array}{c}2 \mathbf{0 . 1 6 5} \\
0.021\end{array}$ & $\begin{array}{cc}2 & \mathbf{0 . 1 3 0} \\
0.031\end{array}$ & $2-3$ & 8 & & $3-4$ \\
\hline Atorella type 1 & $\begin{array}{c}10 \quad \mathbf{0 . 1 6 8} \\
0.017\end{array}$ & $\begin{array}{cc}6 & \mathbf{0 . 1 2 8} \\
0.013\end{array}$ & $6-9$ & 8 & & $5-6$ \\
\hline Atorella type 2 & & & $6-9$ & 8 & present & $10-16$ \\
\hline
\end{tabular}

Table 2. Measurements of collected, complete, undisturbed Brazilian stephanoscyphistomae (Revizee types) and from other cultured species: *Jarms (1988), **Sötje (1998)***Silveira \& Morandini (1997), FQ: Formquotient the ratio between diameter and length, [in Atorella for both types together]; n: number of polyps, mv: mean value, s: standard deviation. 